\title{
Estimation the genetic parameters for milk yield in Romanian Spotted, Simmental type cattle breed
}

\author{
Rodica Ștefania Pelmuș*1, Mircea Cătălin Rotar 1, Cristina Lazăr 1, \\ Răzvan Alexandru Uță 1 \\ *corresponding author: pelmus_rodica_stefania@yahoo.com
}

${ }_{1}$ National Research-Development Institute for Animal Biology and Nutrition, 1, Calea Bucuresti, 077015, Balotesti, Romania

\section{ABSTRACT}

The aim of this study was to estimate the genetic parameters for test-day traits milk yield and the breeding value in Romanian Spotted, Simmental type cattle. Random regression test-day animal model was used to estimate the genetic parameters. The number of records were 2062 test-day from 302 cows. The data were obtained from Romanian Breeding Association Romanian Spotted, Simmental type. The heritability estimates values for milk yield ranged between 0.377 and 0.417 . The heritability for fat test-day yield in our study was low the values ranged between 0.117 and 0.236 and for protein test-day yield was medium, the values ranged between 0.308 and 0.372 .

The breeding value for the best ten cows for milk yield ranged from 1946.57 to $3250.38 \mathrm{~kg}$, for fat yield were between 64.92 and $98.86 \mathrm{~kg}$ and for protein ranged from 67.26 to $102.21 \mathrm{~kg}$. The correlations between test-day milk yields ranging from 0.28 to 1 . Genetic correlations between test day fat and protein yields were high.

Keywords: heritability, correlation, cattle, test-day random regression model

\section{INTRODUCTION}

Romanian Spotted, Simmental type is a dual - purpose breed with a high milk production and a high - quality meat. The breed is found mostly in the Transylvanian Plateau, Banat and North-Eastern of Moldova, inside of Romania. The breed is very well adapted to the climatic conditions in our country.

The largest spread of Simmental breed is in Europe, in particular in Germany and Austria (Perisic et al., 2009). In Romania the population of 
Romanian Spotted, Simmental type has 376000 cattle. This breed has a percentage of $36 \%$ from total cattle herds from Romania. In Romania, the average milk yield of Romanian Spotted ranged between 5000-5700 kg milk, the nutrition and environmental conditions have great influence of milk production.

Test-day random regression model is chosen in developed countries in genetic evaluation of cows (Pandley and Rajak, 2020). This model has the many advantages over the traditional model $(305-d)$. The advantages of this model are: increasing the accuracy of the selection realised by using many records (Ptak and Schaeffer, 1993), reducing production control costs, reducing the generation interval by using monthly records before the end of lactation, the possibility of selection for lactation persistence (Grosu et al., 2019). Swalve (2000) reported that the interest for test-day records increased for the reasons to reduce costs of recording dairy cattle performance. Many authors used the test day animal model in their studies for genetic evaluation in different cattle breeds: Guo and Swalve (1997), Wiggans and Goddard (1997), Jamrozik et al. (1998), Schaeffer (2004), Zavadilova et al. (2005), Mostert (2007). Lidauer et al- (2008) analyze daily milks yields from all parities in German and Austrian Simmental dairy cattle with multiplicative random regression test-day model and observed that this model is important to account for heterogeneous variance in genetic evaluation.

The test-day random regression model improves the accuracy of evaluation. Rotar et al. (2020) show that the test-day animal model determines the more precise estimating in the breeding values. The genetic parameters are useful for the breeding program of this breed for important economic traits.

The genetic parameters are important in the breeding program and to estimate the breeding values.

The aim of this study was the genetic evaluation of test-day traits milk yield of Romanian Spotted, Simmental type.

\section{MATERIALS AND METHODS}

The pedigree consisted of 562 animals from which 302 cows at the first lactation with performances from Romanian Breeding Association Romanian Spotted, Simmental type. The analyzed traits were the milk, fat and protein yields from monthly official records of performances. The data collected in the years 2011-2012 were used in this study.

Restricted maximum likelihood (REML) was used in the study herein.

The script in $\mathrm{R}$ was realized by Horia Grosu. Linear model is described as follows (Grosu and Rotar, 2015, Grosu et al., 2013, Grosu et al., 2019): 


$$
y_{t i j k}=H T D_{i}+\sum_{m=0}^{3}\left(\beta_{m} \cdot z_{t m}\right)+\sum_{m=0}^{3}\left(\alpha_{j m} \cdot z_{t m}\right)+\sum_{m=0}^{3}\left(\gamma_{j m} \cdot z_{t m}\right)+e_{t i j k}
$$

$\mathrm{y}_{\mathrm{tijk}}=$ test day (TD) milk, fat or protein yields

$\mathrm{HTD}_{\mathrm{i}}=$ herd test day fixed effect

$\beta_{\mathrm{m}}=$ fixed regression coefficient;

$\alpha_{j \mathrm{~m}}=$ random regression coefficients for the breeding value;

$\gamma_{j m}=$ random regression coefficients for the permanent environmental effect;

$\mathrm{Z}_{\mathrm{tm}}=$ Legendre Polynomials of order 3 at time " $\boldsymbol{t}$;

$\mathrm{e}_{\mathrm{tijk}}=$ residual error.

Legendre polynomials (Kirpatrik 1990) of order 3 were used in test-day model.

The model is:

$$
y=X_{1} b+X_{2} \beta+Z_{1} \alpha+Z_{2} \gamma+e \text { [2] }
$$

where: $y=$ vector of TD milk, fat or protein yields record;

$\mathrm{X}_{1}=$ incidence matrix for fixed effect

$\mathrm{b}=$ vector of fixed effect for test-day;

$\mathrm{X}_{2}=$ covariates matrix for fixed effect

$\beta=$ fixed regression coefficients

$\mathrm{Z}_{1}=$ covariates matrix for all animals

$\alpha=$ random regression coefficients for the breeding value

$\mathrm{Z}_{2}=$ covariates matrix for cows with records

$\gamma=$ random regression coefficients for the permanent environmental effect

$\mathrm{e}=$ vector of residual effects

The Mixed Model Equations (MME) are:

$$
\left[\begin{array}{cccc}
X_{1}^{\prime} \cdot X_{1} & X_{1}^{\prime} \cdot X_{2} & X_{1}^{\prime} \cdot Z_{1} & X_{1}^{\prime} \cdot Z_{2} \\
X_{2}^{\prime} \cdot X_{1} & X_{2} \cdot X_{2} & X_{2}^{\prime} \cdot Z_{1} & X_{2}^{\prime} \cdot Z_{2} \\
Z_{1}^{\prime} \cdot X_{1} & Z_{1}^{\prime} \cdot X_{2} & Z_{1}^{\prime} \cdot Z_{1}+\left(A^{-1} \otimes G^{-1}\right) \cdot \sigma_{e}^{2} & Z_{1}^{\prime} \cdot Z_{2} \\
Z_{2}^{\prime} \cdot X_{1} & Z_{2}^{\prime} \cdot X_{2} & Z_{2}^{\prime} \cdot Z_{1} & Z_{2}^{\prime} \cdot Z_{2}+\left(I \otimes P^{-1}\right) \cdot \sigma_{e}^{2}
\end{array}\right] \cdot\left[\begin{array}{c}
\tilde{b} \\
\tilde{\beta} \\
\hat{\alpha} \\
\hat{\gamma}
\end{array}\right]=\left[\begin{array}{c}
X_{1}^{\prime} \cdot y \\
X_{2} \cdot \cdot y \\
Z_{1}^{\prime} \cdot y \\
Z_{2}^{\prime} \cdot y
\end{array}\right]
$$

The (co)variance structure was assumed for random effects of model:

$$
\mathrm{V}=\left[\begin{array}{ccc}
\mathrm{A} \otimes \mathrm{G} & 0 & 0 \\
0 & \mathrm{I} \otimes \mathrm{P} & 0 \\
0 & 0 & I \sigma_{e}^{2}
\end{array}\right]
$$

Where:

$$
\begin{aligned}
& \operatorname{Var}(\mathrm{a})=\mathrm{A} \otimes \mathrm{G} ; \\
& \operatorname{Var}(\mathrm{a})=\text { additive variance; }
\end{aligned}
$$


Where $\otimes$ is Kronecker product function;

$\operatorname{Var}(\mathrm{p})=\mathrm{I} \otimes \mathrm{P}$;

$\operatorname{Var}(\mathrm{p})=$ environmental variance;

$\mathrm{G}$ and $\mathrm{P}$ are the matrices of genetic and permanent environmental variances and covariances between random regression coefficients.

$I$ = represents the identity matrix with the size equal with the number of cows with records;

$\sigma_{e}^{2}=$ residual variance for lactation assumed to be constant throughout the lactation;

The formula for heritability was:

where:

$$
h_{t=}^{2} \frac{g_{t t}}{\left(\mathrm{~g}_{t t}+p_{t t}+\sigma_{e}^{2}\right)}
$$

$\mathrm{h}^{2} \mathrm{t}=$ heritability for milk yield during days in milk $\mathrm{t}$;

$\mathrm{g}_{\mathrm{tt}}=$ genetic variance for milk yield during any days in milk $\mathrm{t}$;

$g_{t t}=z_{t}^{\prime} * G * z_{t}$

$p_{t t}=z_{t}^{\prime} * P * z_{t}$

$\mathrm{p}_{\mathrm{tt}}=$ permanent environmental variance for milk yield during any days in milk $\mathrm{t}$;

$\mathrm{Z}_{\mathrm{t}}=$ co(variables) related to a specific test day l measured during days in milk $\mathrm{t}$;

$\sigma^{2}{ }_{\mathrm{e}}=$ residual variance;

where:

$$
r_{g_{t \prime t}}=\frac{g_{t \prime t}}{\sqrt{g_{t \prime t} * g_{t t}}}
$$

$r_{g_{t \prime}}=$ genetic correlations between test-day $\mathrm{t}^{\prime}$ and $\mathrm{t}$ milk yields;

$g_{t \prime t}=$ genetic covariances between two test days during days in milk;

$g_{t, t}=z_{t}^{\prime} * G * z_{t}$

$z_{t \prime}^{\prime}=$ transpose of $\mathrm{z}$;

$E B V_{305}=\sum_{m=0}^{q}\left(\alpha_{j m} \cdot z_{t m}\right)$

$\mathrm{EBV}=$ breeding value estimate

\section{RESULTS AND DISCUSSION}

The matrices $\mathrm{G}$ and $\mathrm{P}$ of genetic and permanent environmental variances and covariances between random regression coefficients were calculated. The results for milk, fat and protein yield were presented. 
The $\mathrm{G}$ and $\mathrm{P}$ matrices for milk yield are:

$$
\begin{gathered}
G=\left[\begin{array}{ccc}
7.31659 & 0.34319 & -0.54540 \\
0.34319 & 1.36980 & -0.03131 \\
-0.54540 & -0.03131 & 0.26096
\end{array}\right] \\
P=\left[\begin{array}{ccc}
2.92663 & 0.13726 & -0.21816 \\
0.13726 & 0.54792 & -0.01252 \\
-0.21816 & -0.01252 & 0.10438
\end{array}\right]
\end{gathered}
$$

The residual variance for milk, fat and protein was calculated. The start residual variance for milk for cattle was taken from the literature (Grosu and Rotar, 2015). The residual variance calculated for milk yield was 12.206 and was used for estimating the breeding values of cows. Maciota et al. (2002) obtained similarly residual variance for milk yield 12.60 .

The $G$ and $P$ matrices for fat yield are:

$$
\begin{gathered}
G=\left[\begin{array}{ccc}
0.014800 & -0.001582 & 0.000113 \\
-0.001582 & 0.002862 & -0.000515 \\
0.000113 & -0.000515 & 0.000647
\end{array}\right] \\
P=\left[\begin{array}{ccc}
0.003254 & -0.000359 & 0.000031 \\
-0.000034 & 0.000010 & -0.000012 \\
0.000031 & -0.000128 & 0.000161
\end{array}\right]
\end{gathered}
$$

The start residual variance for fat was taken from the literature data (Maciota et al. 2012) from Simmental cattle population. The residual variance calculated for fat yield was 0.046 in our study lower that the value obtained by Maciota et al. (2002) obtained for Simmental cows 0.053.

The $G$ and $P$ matrices for protein yield are:

$$
\begin{gathered}
G=\left[\begin{array}{ccc}
0.019350 & 0.001519 & -0.000194 \\
0.001519 & 0.001709 & -0.000703 \\
-0.0001944 & -0.000703 & 0.0000903
\end{array}\right] \\
P=\left[\begin{array}{ccc}
0.004243 & 0.000336 & -0.000047 \\
0.000336 & 0.000420 & -0.000174 \\
-0.0000472 & -0.000174 & 0.000022
\end{array}\right]
\end{gathered}
$$

The start residual variance for protein was taken from the literature data (Maciota et al. 2012) from Simmental cattle population. The residual variance for protein yield was 0.020 higher than the value 0.018 obtained by Maciotta et al. (2002). 
Table 1 has shown the average records for test-day milk yield. Milk yield increased and reached its maximum in test day two and then decreased in the following test-days.

The average test-day milk yield was $18.18 \mathrm{~kg}$ for Romanian Spotted cows, Simmental type from our study and the mean milk yield in 305 days of lactation was $5545 \mathrm{~kg}$. Gantner et al. (2009) obtained a lower mean for test day milk yield of $18 \mathrm{~kg}$ in Simmental breed. Bonfatti et al. (2010) found a higher mean for test day milk yield $26.18 \mathrm{~kg}$ than in our study. Bolacali and Ozturk (2018) reported a higher mean than in our study of $6413.04 \mathrm{~kg}, 6060$ $\mathrm{kg}$ and $6871.21 \mathrm{~kg}$ in 305 days in milk in Simmental cattle. Petrovic et al. (2009) obtained a mean lower than in our study of $4765 \mathrm{~kg}$ milk of Simmental cows in Serbia. Similarly, Cilek et al. (2008) found lower average records in Simmental cattle from Turkey than in our study. The mean of 305 days milk yield was $4519 \mathrm{~kg}$ in this population lower than in our study.

Table 1. Test day milk yield in Romanian Spotted, Simmental type cows

\begin{tabular}{cccc}
\hline Test day & $\begin{array}{c}\text { Mean } \pm \text { mean } \\
\text { error }\end{array}$ & $\begin{array}{c}\text { Standard } \\
\text { deviation }\end{array}$ & Number of cows \\
\hline 1 & $20.09 \pm 0.58$ & 5.59 & 93 \\
2 & $20.90 \pm 0.48$ & 5.19 & 117 \\
3 & $20.40 \pm 0.53$ & 6.31 & 140 \\
4 & $20.08 \pm 0.50$ & 6.17 & 152 \\
5 & $19.04 \pm 0.41$ & 5.56 & 177 \\
6 & $18.56 \pm 0.40$ & 5.58 & 194 \\
7 & $18.37 \pm 0.38$ & 5.68 & 223 \\
8 & $17.62 \pm 0.35$ & 5.57 & 240 \\
9 & $16.60 \pm 0.34$ & 5.45 & 250 \\
10 & $16.67 \pm 0.38$ & 5.76 & 224 \\
11 & $16.19 \pm 0.39$ & 5.06 & 166 \\
12 & $16.31 \pm 0.58$ & 5.43 & 86 \\
\hline MEAN: & $\mathbf{1 8 . 1 8} \pm \mathbf{0 . 1 2}$ & $\mathbf{5 . 8 2}$ &
\end{tabular}

Table 2 shows the mean and standard deviation for fat milk test-day yield. The fat yield is greater in the first three test-days and then decreases in the following test-days.

Gantner et al. (2009) obtained a mean of $0.75 \mathrm{~kg}$ for fat milk test-day yield higher than in our study. Bonfatti et al. (2010) found a mean for fat milk test day yield $1.02 \mathrm{~kg}$ higher than in our study. 
Table 2. Test day fat milk yield in Romanian Spotted, Simmental type cows

\begin{tabular}{cccc}
\hline Test day & $\begin{array}{c}\text { Mean } \pm \text { mean } \\
\text { error }\end{array}$ & $\begin{array}{c}\text { Standard } \\
\text { deviation }\end{array}$ & Number of cows \\
\hline 1 & $0.82 \pm 0.027$ & 0.26 & 93 \\
2 & $0.82 \pm 0.023$ & 0.25 & 117 \\
3 & $0.82 \pm 0.026$ & 0.30 & 140 \\
4 & $0.80 \pm 0.023$ & 0.28 & 152 \\
5 & $0.76 \pm 0.020$ & 0.27 & 177 \\
6 & $0.73 \pm 0.019$ & 0.27 & 194 \\
7 & $0.74 \pm 0.016$ & 0.24 & 223 \\
8 & $0.71 \pm 0.014$ & 0.23 & 240 \\
9 & $0.68 \pm 0.015$ & 0.24 & 250 \\
10 & $0.69 \pm 0.017$ & 0.26 & 224 \\
11 & $0.68 \pm 0.010$ & 0.18 & 166 \\
12 & $0.68 \pm 0.020$ & 0.23 & 86 \\
\hline MEAN: & $\mathbf{0 . 7 4 \pm 0 . 0 5}$ & $\mathbf{0 . 2 6}$ & \\
\hline
\end{tabular}

Table 3 presents the mean and standard deviation for protein milk test-day yield. Test-day protein milk yield increased and reached its maximum in test day two and then decreased in the following test-days. Gantner et al. (2009) obtained a mean of $0.63 \mathrm{~kg}$ for protein milk test-day higher than in our study. Bonfatti et al. (2010) found a mean for protein test day milk yield $0.92 \mathrm{~kg}$ higher than in our study.

Table 3. Test day protein milk yield in Romanian Spotted, Simmental type cows

\begin{tabular}{cccc}
\hline Test day & $\begin{array}{c}\text { Mean } \pm \text { mean } \\
\text { error }\end{array}$ & $\begin{array}{c}\text { Standard } \\
\text { deviation }\end{array}$ & Number of cows \\
\hline 1 & $0.67 \pm 0.021$ & 0.58 & 93 \\
2 & $0.68 \pm 0.018$ & 0.19 & 117 \\
3 & $0.67 \pm 0.010$ & 0.23 & 140 \\
4 & $0.66 \pm 0.018$ & 0.22 & 152 \\
5 & $0.64 \pm 0.019$ & 0.21 & 177 \\
6 & $0.63 \pm 0.014$ & 0.20 & 194 \\
7 & $0.62 \pm 0.013$ & 0.20 & 223 \\
8 & $0.60 \pm 0.010$ & 0.19 & 240 \\
9 & $0.58 \pm 0.015$ & 0.19 & 250 \\
10 & $0.59 \pm 0.013$ & 0.20 & 224 \\
11 & $0.57 \pm 0.014$ & 0.18 & 166 \\
12 & $0.59 \pm 0.020$ & 0.02 & 86 \\
\hline MEAN: & $\mathbf{0 . 6 2} \pm \mathbf{0 . 0 4}$ & $\mathbf{0 . 2 1}$ &
\end{tabular}



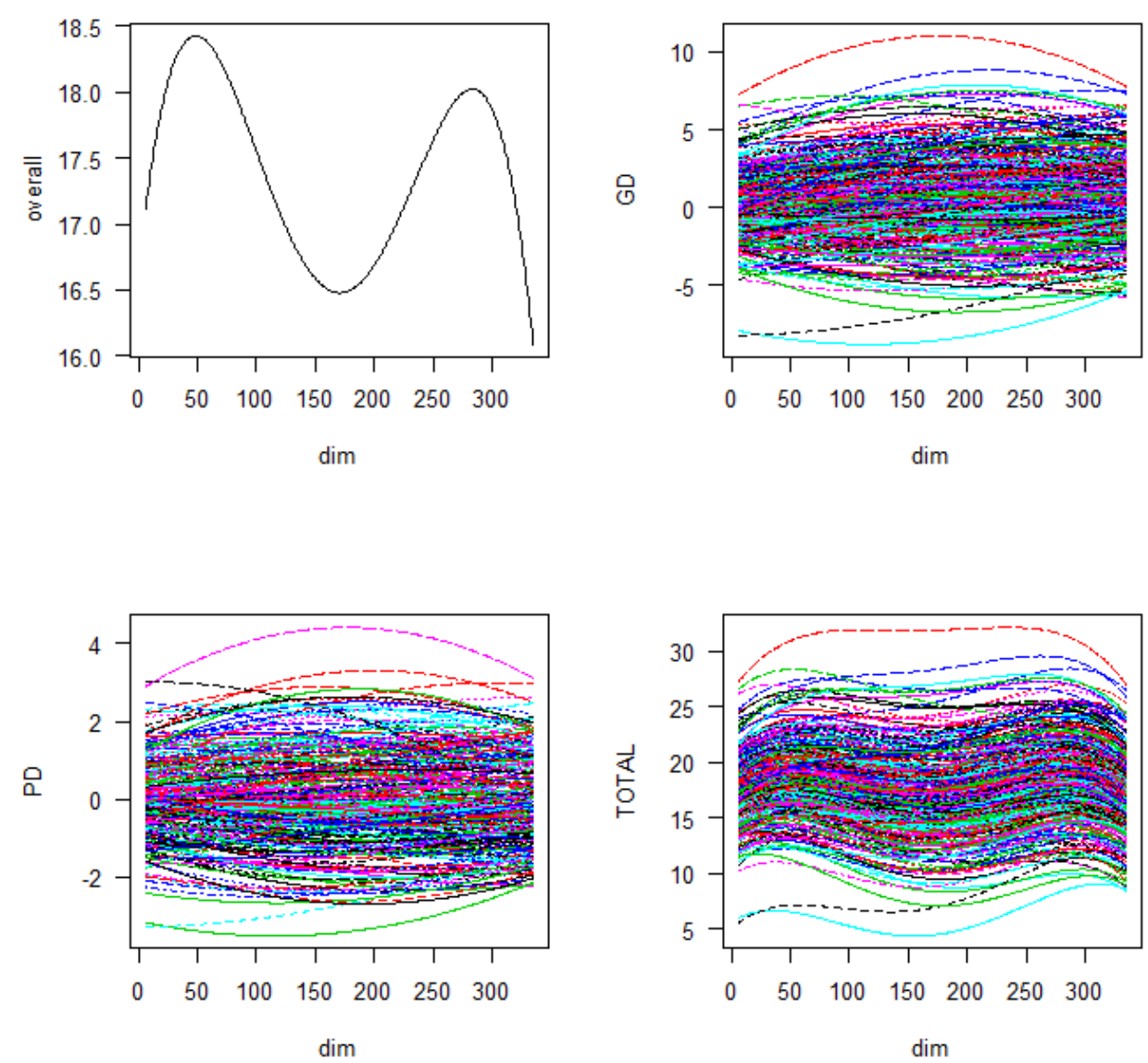

Figure 1- Overall lactation curve for standard days in milk

Figure 2- Breeding values curve of lactation

Figure 3 -Permanent effect curve of lactation

Figure 4- Phenotypic curve of lactation

Overall lactation curve is presented in Figure 1 as the evolution of average milk production for all cows from study in relation to the stage of lactation. In figures 2, 3 and 4 are presented the three components of individual curve of lactation: breeding values, permanent effect and phenotypic curve of lactation for milk. 

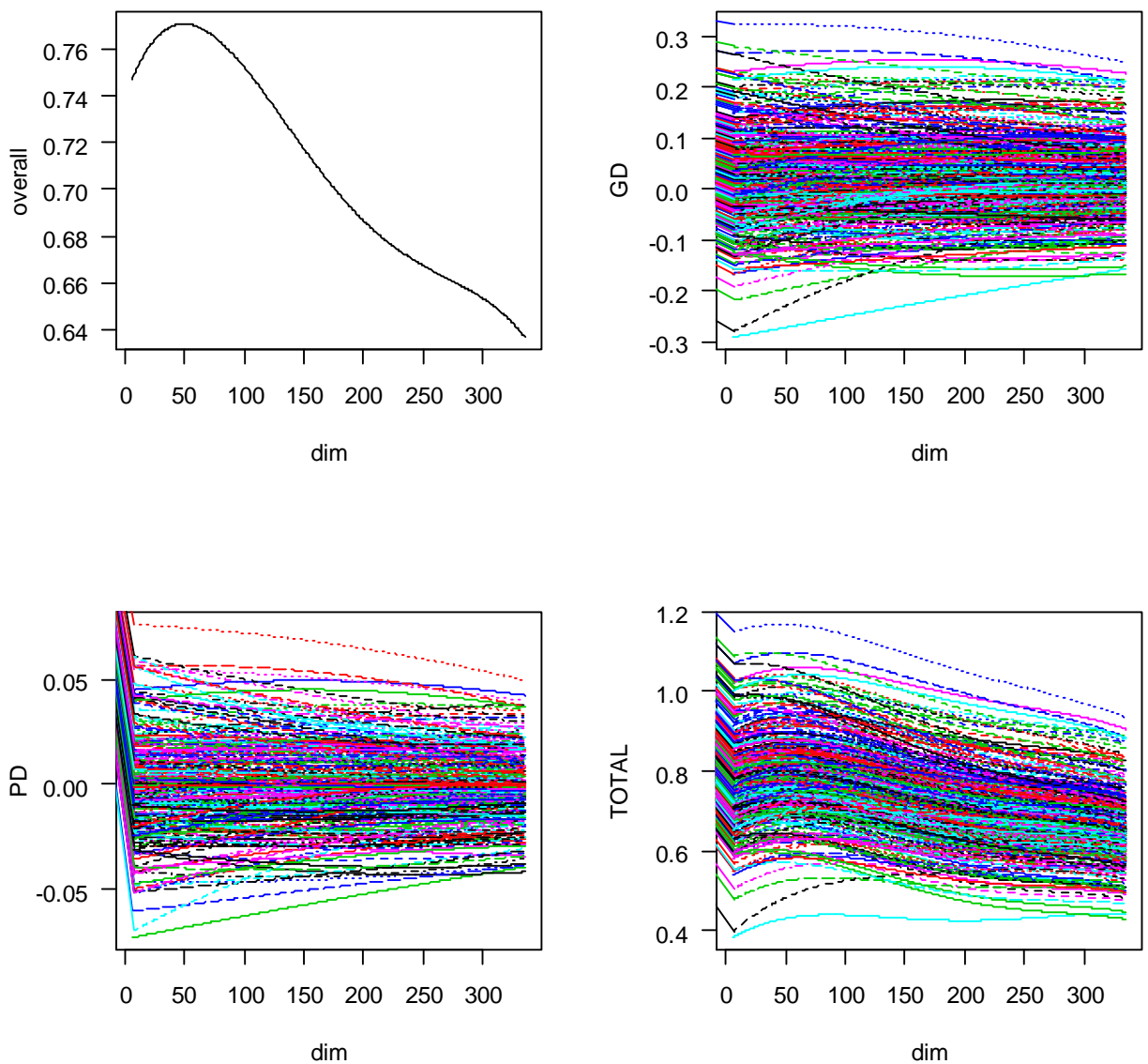

Figure 5- Overall lactation curve for standard days in milk for fat milk Figure 6- Breeding values curve of lactation for fat milk Figure 7 -Permanent effect curve of lactation for fat milk Figure 8- Phenotypic curve of lactation for fat milk

Overall lactation curve is presented in Figure 5 as the evolution of average fat milk production for all cows from study in relation to the stage of lactation. In figures 6, 7 and 8 are presented the three components of individual curve of lactation: breeding values, permanent effect and phenotypic curve of lactation for fat milk. 

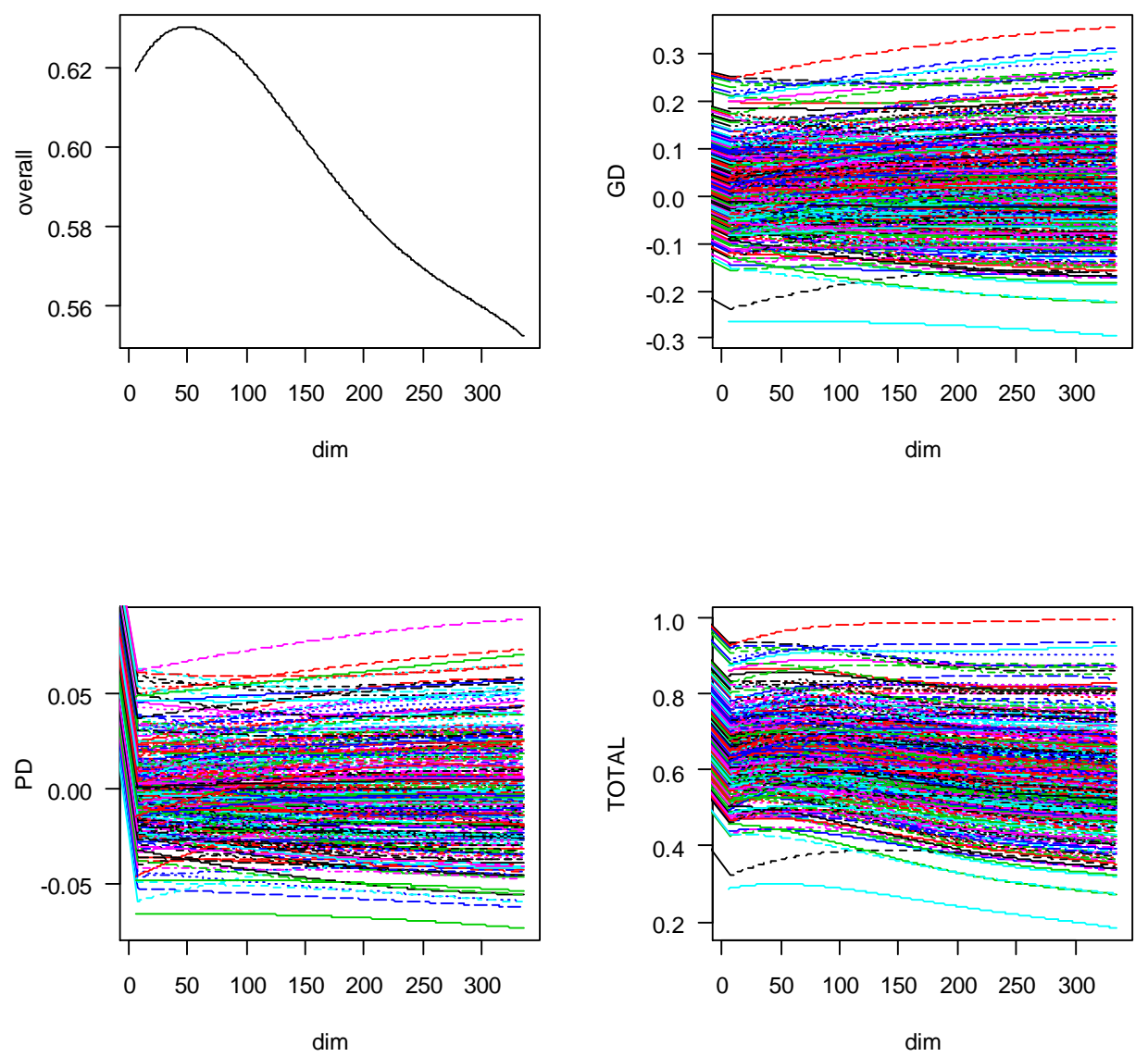

Figure 9- Overall lactation curve for standard days in milk for protein milk Figure 10- Breeding values curve of lactation for protein milk Figure 11-Permanent effect curve of lactation for protein milk Figure 12- Phenotypic curve of lactation for protein milk

Overall lactation curve is presented in Figure 9 as the evolution of average protein milk production for all cows from study in relation to the stage of lactation. In figures 10, 11 and 12 are presented the three components of individual curve of lactation: breeding values, permanent effect and phenotypic curve of lactation for protein milk. 
Table 4 shows the heritability for test-day traits milk yield for first lactation of Romanian Spotted, Simmental type. The heritability for milk yield ranged between 0.377 and 0.417 for the cows at first lactation, the heritability for 305 days in milk was 0.389 . The heritability was the highest in the late lactation and medium in middle of lactation.

The lower heritability than in our study was obtained by different authors. The estimated heritability in our study was higher than estimated heritability found by Emmerling et al. (2002) for Simmental cattle in first lactation in Germany ranged between $0.20-0.28$. For example, the heritability for milk yield found by Nistor et al. (2011) was 0.144 in Romanian Simmental dairy cows. Cilek et al. (2008) obtained also the low heritability for the test day milk yield of 0.14 in Simmental cows from Turkey.

Amaya et al. (2019) obtained the estimates values heritability for milk production for 60 days, 150 days and 305 days ranged from 0.20 to $0.27,0.25$ to $0.52,0.30$ to 0.35 and 0.20 to 0.23 . For 150 days, the value heritability of 0.52 for milk yield was higher than in the study herein. Yang et al. (2005) reported heritability for milk yield for 305 days 0.34 in Simmental cows from China. Kaps and Spehar (2004) obtained 0.36 heritability for milk yield in Croatian Simmental. The heritability for fat test-day yield in our study was low the values ranged between 0.117 and 0.236 , the heritability for 305 days in milk was 0.136 . The heritability for protein test-day yield was medium the values ranged between 0.308 and 0.372 , the heritability for 305 days in milk was 0.356. Nistor et al. (2011) reported the heritability for Romanian Simmental for fat yield 0.287 higher than our study and for protein yield was 0.280 lower than study herein. Kaps and Spehar (2004) obtained higher heritability for fat yield for 305 days 0.31 and lower heritability 0.27 for protein yield for Simmental cattle than in our study. Cho et al. (2016) reported low test-day heritability estimates ranged from 0.08 to 0.15 for milk, 0.06 to 0.14 for fat, 0.08 to 0.12 for protein according to days in milk in Holstein breed cows. Kheirabadi and Razmkabir (2016) observed low heritability estimates for milk 0.204 , fat 0.096 and protein 0.047 to Holstein cattle. 
Table 4. The heritability in Romanian Spotted, Simmental type cattle in first lactation for test-days milk, fat and protein yield

\begin{tabular}{cccc}
\hline $\begin{array}{c}\text { Days in } \\
\text { milk }\end{array}$ & $\begin{array}{c}\text { Heritability } \\
\text { for milk yield }\end{array}$ & $\begin{array}{c}\text { Heritability } \\
\text { for fat yield }\end{array}$ & $\begin{array}{c}\text { Heritability } \\
\text { for protein yield }\end{array}$ \\
\hline 5 & 0.401 & 0.236 & 0.363 \\
35 & 0.382 & 0.193 & 0.331 \\
65 & 0.377 & 0.163 & 0.313 \\
95 & 0.381 & 0.143 & 0.308 \\
125 & 0.387 & 0.131 & 0.313 \\
155 & 0.394 & 0.125 & 0.325 \\
185 & 0.398 & 0.121 & 0.340 \\
215 & 0.401 & 0.118 & 0.353 \\
245 & 0.403 & 0.117 & 0.364 \\
275 & 0.408 & 0.118 & 0.371 \\
305 & 0.417 & 0.124 & 0.372 \\
Total 305 days & 0.389 & 0.136 & 0.356
\end{tabular}

The breeding value for the best ten cows for milk yield ranged from 1946.57 to $3250.388 \mathrm{~kg}$ milk, for fat yield were between 64.92 and $98.86 \mathrm{~kg}$ and for protein ranged from 67.26 to $102.21 \mathrm{~kg}$. Rotar et al. (2016) used also the test-day random regression model to estimate the breeding value for milk yield in cows from other breeds like Montbeliarde, Black Spotted Romanian and Brown.

Table 5a. Breeding value of the best Romanian Spotted, Simmental type cattle in the first lactation for milk, fat and protein yield

\begin{tabular}{cccc}
\hline No & $\begin{array}{c}\text { Breeding } \\
\text { values milk } \\
\text { yield }\end{array}$ & $\begin{array}{c}\text { Breeding } \\
\text { values fat } \\
\text { yield }\end{array}$ & $\begin{array}{c}\text { Breeding } \\
\text { values protein } \\
\text { yield }\end{array}$ \\
\hline 1 & 3250.388 & 98.86 & 102.21 \\
2 & 2506.608 & 84.14 & 88.41 \\
3 & 2211.204 & 80.82 & 85.15 \\
4 & 2205.578 & 77.83 & 84.28 \\
5 & 2191.586 & 69.76 & 80.82 \\
6 & 2163.886 & 69.12 & 79.95 \\
7 & 2134.456 & 67.66 & 79.40 \\
8 & 2077.289 & 66.84 & 77.13 \\
9 & 1963.438 & 65.52 & 74.17 \\
10 & 1946.574 & 64.92 & 67.26 \\
\hline
\end{tabular}

In table $5 \mathrm{~b}$ are presented the relative breeding values for the best cows from this study. The first cow presented a relative breeding value for milk $129.30 \%$, for fat $121.90 \%$ and for protein yields $127.02 \%$. 
Table 5b. Relative Breeding value of the best Romanian Spotted, Simmental type cattle in the first lactation for milk, fat and protein yield

\begin{tabular}{cccc}
\hline No & $\begin{array}{c}\text { Relative } \\
\text { breeding } \\
\text { values milk } \\
\text { yield (\%) }\end{array}$ & $\begin{array}{c}\text { Relative } \\
\text { breeding } \\
\text { values fat } \\
\text { yield (\%) }\end{array}$ & $\begin{array}{c}\text { Relative } \\
\text { breeding } \\
\text { values protein } \\
\text { yield (\%) }\end{array}$ \\
\hline 1 & 129.309 & 121.900 & 127.027 \\
2 & 122.602 & 118.639 & 123.376 \\
3 & 119.938 & 117.904 & 122.514 \\
4 & 119.888 & 117.241 & 122.284 \\
5 & 119.761 & 115.454 & 121.369 \\
6 & 119.512 & 115.312 & 121.139 \\
7 & 119.246 & 114.988 & 120.994 \\
8 & 118.731 & 114.807 & 120.394 \\
9 & 117.704 & 114.514 & 119.611 \\
10 & 117.552 & 114.381 & 117.784 \\
\hline
\end{tabular}

In table 6 gives the correlations between test-day milk yields. The genetic correlations between test days milk yield are high on the early consecutive tests. Then, the genetic correlations decrease. For example, correlation between DIM 35 and DIM 65 was 0.97 (high corelated) and the other side, if we are looking at correlation between DIM 35 and DIM 305 can observed a decrease of it (0.41).

Table 6. Genetic correlation estimates between selected days in milk (DIM) of daily yields (first lactation)

\begin{tabular}{l|lllllllllll}
\hline \multicolumn{1}{l}{ DIM } & 5 & 35 & 65 & 95 & 125 & 155 & 185 & 215 & 245 & 275 & 305 \\
\hline 5 & 1 & 0.97 & 0.90 & 0.82 & 0.73 & 0.64 & 0.56 & 0.49 & 0.42 & 0.35 & 0.28 \\
35 & & 1 & 0.97 & 0.92 & 0.86 & 0.79 & 0.72 & 0.65 & 0.58 & 0.49 & 0.41 \\
65 & & & 1 & 0.98 & 0.94 & 0.89 & 0.84 & 0.78 & 0.71 & 0.62 & 0.53 \\
95 & & & & 1 & 0.98 & 0.96 & 0.92 & 0.87 & 0.80 & 0.71 & 0.62 \\
125 & & & & & 1 & 0.99 & 0.96 & 0.93 & 0.87 & 0.79 & 0.70 \\
155 & & & & & & 1 & 0.99 & 0.96 & 0.92 & 0.85 & 0.77 \\
185 & & & & & & & 1 & 0.99 & 0.96 & 0.90 & 0.83 \\
215 & & & & & & & & 1 & 0.98 & 0.95 & 0.89 \\
245 & & & & & & & & & 1 & 0.98 & 0.95 \\
275 & & & & & & & & & & 1 & 0.98 \\
305 & & & & & & & & & & & \\
\hline
\end{tabular}

In table 7 shows the correlations between test-day fat yields. The genetic correlations between test days fat yield are very high. 
Table 7. Genetic correlation estimates between test days fat yield

\begin{tabular}{l|lllllllllll}
\hline DIM & 5 & 35 & 65 & 95 & 125 & 155 & 185 & 215 & 245 & 275 & 305 \\
\hline 5 & 1 & 0.98 & 0.94 & 0.86 & 0.77 & 0.68 & 0.59 & 0.52 & 0.47 & 0.43 & 0.41 \\
35 & & 1 & 0.98 & 0.93 & 0.86 & 0.78 & 0.71 & 0.64 & 0.58 & 0.53 & 0.50 \\
65 & & & 1 & 0.98 & 0.94 & 0.88 & 0.81 & 0.75 & 0.69 & 0.63 & 0.58 \\
95 & & & & 1 & 0.98 & 0.95 & 0.90 & 0.85 & 0.79 & 0.73 & 0.66 \\
125 & & & & & 1 & 0.98 & 0.96 & 0.92 & 0.87 & 0.80 & 0.73 \\
155 & & & & & & 1 & 0.99 & 0.96 & 0.92 & 0.86 & 0.79 \\
185 & & & & & & & 1 & 0.99 & 0.96 & 0.91 & 0.85 \\
215 & & & & & & & & 1 & 0.99 & 0.95 & 0.90 \\
245 & & & & & & & & & 1 & 0.98 & 0.95 \\
275 & & & & & & & & & & 1 & 0.98 \\
305 & & & & & & & & & & & 1 \\
\hline
\end{tabular}

In table 8 are the correlations between test-day protein yields. The genetic correlations between test days protein yield are also very high, same as in the case of fat yield.

Table 8. Genetic correlation estimates between test days protein yield

\begin{tabular}{l|lllllllllll}
\hline \multicolumn{1}{l}{ DIM } & 5 & 35 & 65 & 95 & 125 & 155 & 185 & 215 & 245 & 275 & 305 \\
\hline 5 & 1 & 0.98 & 0.94 & 0.87 & 0.79 & 0.71 & 0.65 & 0.60 & 0.57 & 0.56 & 0.56 \\
35 & & 1 & 0.98 & 0.94 & 0.88 & 0.82 & 0.77 & 0.73 & 0.71 & 0.70 & 0.71 \\
65 & & & 1 & 0.98 & 0.95 & 0.91 & 0.87 & 0.84 & 0.82 & 0.82 & 0.84 \\
95 & & & & 1 & 0.98 & 0.96 & 0.94 & 0.92 & 0.91 & 0.91 & 0.93 \\
125 & & & & & 1 & 0.99 & 0.98 & 0.97 & 0.96 & 0.97 & 0.98 \\
155 & & & & & & 1 & 0.99 & 0.99 & 0.99 & 0.99 & 1 \\
185 & & & & & & & 1 & 0.99 & 1 & 1 & 1 \\
215 & & & & & & & & 1 & 1 & 1 & 1 \\
245 & & & & & & & & & 1 & 1 & 1 \\
275 & & & & & & & & & & 1 & 1 \\
305 & & & & & & & & & & & 1 \\
\hline
\end{tabular}

\section{CONCLUSION}

The heritability for test day milk yield in Romanian Spotted, Simmental type cattle was higher at the beginning and to the end of lactation and medium in middle of lactation. The heritability estimates for test-day milk yield of cows at first lactation ranged between 0.377 and 0.417 . Genetic correlations between test day milk yield ranged between 0.28 to 1 . We can conclude that at the beginning and the ending of lactation we have a higher genetic variance, fact that gives us higher heritability.

The heritability for fat test-day yield in our study was low the values ranged between 0.117 and 0.236 , the heritability for 305 days in milk was 
0.136. The heritability for protein test-day yield was medium, the values ranged between 0.308 and 0.372 , the heritability for 305 days in milk was 0.356 . Genetic correlations between test day fat and protein yields between were high.

\section{ACKNOWLEDGEMENTS}

This work was supported by funds from the National Research Project 8.1.10 and 8.1.6. granted by the Romanian Ministry of Agriculture and Rural Development and by Romanian Breeding Association Romanian Spotted, Simmental type.

\section{REFERENCES}

Amaya, A., Martinez, R., Ceron-Munoz, 2019. Genetic paramaters milk production in Simmental cattle using genomic and polygenic models. Rev. Med. Vet Zoot. , 66, 2, 131-140.

Bolacali, M., Ozturk, Y., 2018. Effect of non- genetic factors on milk yields traits in Simmental cows raised subtropical climate condition. Arq. Bras. Med. Vet. Zootechn, 70, 1, 297-305

Bonfatti, V., Martino, G.Di, Cecchinato, A., Vicario, D., Carnier, P., 2010. Effects of $\beta$-k-casein (CSN2-CSN3) haplotypes and $\beta$ lactoglobulin (BLG) genotypes on milk production traits and detailed protein composition of individual milk of Simmental cows. Journal of Dairy Science, 93, 8, 3797-3808.

Cho, C.I., Alam, M., Choi, T.J., Choy, Y.H., Choi, J.G., Lee, S.S., Cho, K.H., 2016. Models for estimating genetic parameters of milk production traits using random regression models in Korean Holstein cattle. Asian Australas. J. Anim. Sci., 29, 5, 607-614.

Cilek, S., Orhan H., Kaygisiz, A., Hesna Sahin, E., 2008. Estimation of breeding values of Anatolian population of Simmental cows using monthly testday milk yields. Archiva Zootechnica, 11, 4, 79-85.

Emmerling, R., Lidauer, M., Mäntysaari, E.A., 2002. Multiple lactation random regression test-day model for Simmental and Brown Swiss in Germany and Austria. Interbull Bulletin, 29, 111-117.

Gantner, V., Jovanovac, S., Klopcčič, M., Cassandro, M., Roguž, N., Kutervac, K., 2009. Methods for estimation of daily and lactation milk yields from alternative milk recording scheme in Holstein and Simmental cattle breeds. Ital. J. Anim. Sci., 8, 519-530.

Grosu, H., Rotar M.C., 2015. Estimation of breeding values in cattle with testday models. Ceres, Bucuresti. 
Grosu, H., Schaeffer, L., Oltenacu, P.A., Norman, D., Powell, R., Kremer, V., Banos, G., Mrode, R., Carvalheira, J., Jamrozik, J., Draganescu, C., Lungu, S., 2013. History of genetic evaluation methods in dairy cattle. The Publishing House of the Romanian Academy, Bucharest.

Grosu, H., Lungu, S., Oltenacu, P.A., Drăgănescu, C., Mateescu, R., 2019. The prediction of breeding values of cattle. The Publishing Ceres, Bucharest.

Guo, Z., Swalve H.H., 1997. Comparison of different lactation curve sub-models in test day models. Interbul Mtg Vienna, International Bull Evaluations Service, Uppsala, Sweden. Interbull Bull, 16, 75-79.

Jamrozik, J., Jansen G., Schaeffer L.R., Liu Z., 1998. Analysis of persistency of lactation calculated from a random regression test day model. Proc. Interbull Mtg Rotorua, International Bull Evaluations Service, Uppsala, Sweden, Interbull Bull, 17, 64-69.

Kaps, M., Spehar, M, 2004. Estimation of genetic parameters and breeding values of milk traits for Simmental cattle in Croatia using a lactation animal model. Agric. Conspectus Scientificus, 69, 91-94.

Kheirabadi, K., Razmkabir, M., 2016. Genetic parameters for daily milk somatic cell score and relationship with yield traits of primiparous Holstein cattle in Iran. Journal of Animal Science and Technology, 58, 38.

Kirkpatrick, M., Lofsvold D., Bulmer M., 1990. Analysis of inheritance, selection and evolution of growth trajectories, Genetics, 124, 979-993.

Lidauer, M.H., Emmerling, R., Mantysaari, E.A., 2008. Multiplicative random regression model for heterogeneous variance adjustment in genetic evaluation for milk yield in Simmental. J. Anim. Breed. Genet, 125, 147159.

Macciotta, N.P.P., Vicario D., Pulina G., Cappio-Borlino A., 2002. Test day and lactation yield predictions in Italian Simmental cows by ARMA methods. Journal Dairy Science 85, 3107-3114.

Mostert, B.E., 2007. The suitability of test-day models for genetic evaluation of dairy cattle in South Africa. PhD thesis, University of Pretoria, South Africa.

Nistor, E., Bampidis, V.A., Pentea, M., Matiuți, M., Ciolac, V., Adebambo, F., 2011. Genetic and phenotypic parameters for milk production traits in the first and second lactation in Romanian Simmental dairy cows. Iranian Journal of Applied Animal Science, 1(4), 257-263.

Pandey, M., Rajak, N., 2020. Random regression model as a tool for genetic evaluation of test day milk yields in animal breeding: A review. PantnagarJournal of Research, 18,1, 103-111.

Perisic, P., Shalicki, Z., Petrovic, M.M., Bogdanovic, V., Ruzic-Muslic, D., 2009. Simmental cattle breed in different production systems. Biotechnology in Animal Husbandry, 25, 5-6, 315-326.

Petrovic, M.M., Sretenovic Lj., Aleksic, S., Pantelic, V., Novakovic, Z., Perisic, P., Petrovic, M.D., 2009. Investigation of the heritability of phenotypes of 
ferility and milk performance of Simmental cattle breed in Serbia. Biotechnology in Animal Husbandry, 25, 5-6, 285-292.

Ptak, E., Schaeffer, L. R., 1993. Use of test day yields for genetic evaluation of dairy cattle. Livestock Production Science, 34-23.

Rotar, M.C., Grosu, H., Gras, M.A., Pelmuș, R.S., Lazăr, C., 2016. Comparative research on breeding value prediction for milk yield in cattle. Agriculture and Agricultural Science Procedia,10, 311-317.

Rotar, M.C., Grosu, H., Gras, M.A., Pelmuș, R.S., Lazăr, C, Popa F., 2020. Animal model versus polynomial Legendre test-day in dairy cattle. Archiva Zootechnica, 23, 1, 5-12.

Schaeffer, L.R. 2004. Applicaion of random regression models in animal breeding. Livestock Production Science, 86, 35-45.

Yang, R.Q., Ren, H.Y., Schaeffer, L.R., Xu, S.Z., 2005. Estimation of genetic parameters for lactational milk yields using two-dimensional random regressions on parities and days in milk in Chinese Simmental cattle. J. Anim Breed Genet, 1, 49-55.

Swalve, H.H., 2000. Theoretical basis and computational methods for different test-day genetic evaluation methods. Journal of Dairy Science 83, 1115-1124.

Wiggans, G.R., Goddard, M.E., 1997. A computationally feasible test day model for genetic evaluation of yield trait in the United States. Journal of Dairy Science, 80, 1795-1800.

Zavadilova, L., Nemcova, E., Pribyl, J., Wolf, J., 2005. Definition of sub-groups for fixed regressin in test-day animal model for milk production of Holstein cattle in the Czech Republic. Czech Journal of Animal Science, 50, 1, 7-13. 